\title{
Analysis of the caregiver burden associated with Sanfilippo syndrome type B: panel recommendations based on qualitative and quantitative data
}

Elsa Shapiro ${ }^{1,2^{*}}$ (D) Charles Marques Lourenço ${ }^{3}$, Neslihan Onenli Mungan ${ }^{4}$, Nicole Muschol ${ }^{5}$, Cara $^{\prime} \mathrm{O}^{\prime}$ eill $^{6}$ and Suresh Vijayaraghavan ${ }^{7}$

\begin{abstract}
Background: Sanfilippo syndrome type B (Sanfilippo B) belongs to a group of rare lysosomal storage diseases characterized by progressive cognitive decline from an early age, acute hyperactivity, and concomitant somatic symptoms. Caregivers face a unique set of challenges related to the complex nature of Sanfilippo B, but the burden and impact on quality of life (QoL) of caregivers is poorly defined and best practice guidance for clinicians is lacking.

Methods: An international clinical advisors meeting was convened to discuss key aspects of caregiver burden associated with Sanfilippo B based on findings from qualitative and quantitative research undertaken to identify and quantify the nature and impact of the disease on patients and caregivers.

Results: Providing care for patients with Sanfilippo B impinges on all aspects of family life, evolving as the patient ages and the disease progresses. Important factors contributing toward caregiver burden include sleep disturbances, impulsive and hyperactive behavior, and communication difficulties. Caregiver burden remained high throughout the life of the patient and, coupled with the physical burden of daily care, had a cumulative impact that generated significant psychological stress.
\end{abstract}

Conclusion: A Sanfilippo-specific QoL questionnaire is needed that is directed at caregiver needs and burden and best practice management of these domains.

Keywords: Sanfilippo syndrome, Caregiver, Burden of disease, Quality of life

\section{Background}

Mucopolysaccharidosis type III (MPS III; also known as Sanfilippo syndrome), a group of rare, genetic lysosomal storage disorders, is characterized by a deficiency in 1 of 4 enzymes involved in the degradation of the glycosaminoglycan heparan sulfate, resulting in progressive cell damage and multisystem disease [1-5]. Four subtypes of Sanfilippo syndrome (A-D) have been identified based on the specific enzyme deficiency $[1,2]$, along with their underlying

\footnotetext{
* Correspondence: eshapiro@shapironeuropsych.com

'Shapiro Neuropsychology Consulting, LLC, 820 NW 12th Avenue, Portland, OR 97209, USA

2University of Minnesota, Minneapolis, MN, USA

Full list of author information is available at the end of the article
}

genotypes [5]. In studies, the incidence of Sanfilippo syndrome subtypes ranges between 0.28 and 4.1 per 100,000 live births depending on geographic region, with types $\mathrm{A}$ and $\mathrm{B}$ being more common than types $\mathrm{C}$ and $\mathrm{D}$ [6-8].

Patients with Sanfilippo syndrome type B (Sanfilippo B) are deficient in the lysosomal enzyme, alpha-Nacetylglucosaminidase, which is involved in heparan sulfate degradation [2]. This deficiency causes large amounts of heparan sulfate to accumulate in the cells and tissues of the body $[2,4]$. As a result, progressive cellular damage occurs and patients present with a spectrum of symptoms that progress with age and affect multiple organ systems. Brain disease leads to cognitive impairment and ultimately severe morbidity

(c) The Author(s). 2019 Open Access This article is distributed under the terms of the Creative Commons Attribution 4.0 International License (http://creativecommons.org/licenses/by/4.0/), which permits unrestricted use, distribution, and reproduction in any medium, provided you give appropriate credit to the original author(s) and the source, provide a link to the Creative Commons license, and indicate if changes were made. The Creative Commons Public Domain Dedication waiver (http://creativecommons.org/publicdomain/zero/1.0/) applies to the data made available in this article, unless otherwise stated. 
and premature death [4]. Symptoms generally begin between the ages of 2 and 6 years and include slowing in developmental milestones and language acquisition, hyperactivity usually unresponsive to medication, and sleep disorders and disruptive behavior sometimes perceived as aggression that may predate the diagnosis of Sanfilippo syndrome $[1,9]$.

The progression of Sanfilippo B occurs across 3 loosely defined phases. A period of normal development is followed by various stages of neurocognitive and somatic signs and symptoms that vary in severity depending on disease phenotype [8]. An attenuated phenotype, sometimes presented by patients with Sanfilippo B, involves a slower progression of symptoms and longer lifespan than those with the rapidly progressing form of the disease, for which life expectancy is severely shortened $[8,10]$. Mortality has been reported to range from the second to seventh decade of life and pneumonia is a leading cause of death $[3,10]$. Early diagnosis in the slow-progressing population is more challenging and patients may remain undiagnosed until adulthood [8]. In a single-center study, diagnosis occurred earlier in patients with the rapidly progressing phenotype of Sanfilippo syndrome (54 months; range, 34-79 months) than in patients with the attenuated phenotype (71 months; range, 20-522 months) [11]. Symptoms of Sanfilippo B can also masquerade as a behavioral disorder. Several reports have shown patients to present with symptoms consistent with a variety of behavioral disorders, including autism and attention deficit hyperactivity disorder, which have resulted in incomplete or delayed diagnosis of Sanfilippo syndrome [5, 12-15].

Care for patients with Sanfilippo B is provided primarily by parents, but siblings, relatives, partners, or professional caregivers may also provide support. [16]. The burden on caregivers has a wide impact on all dimensions of day-to-day family life that extends to the physical and psychological wellbeing of the caregivers. $[4,16]$. Caregivers may experience a high physical burden from coping with the effects of behavioral difficulties (eg, hyperactivity and impulsiveness), sleep disturbances, and somatic symptoms (eg, respiratory infections and gastrointestinal disturbances) [8]. Although little research has been published regarding caregiver burden in Sanfilippo B, survey findings of caregivers of Sanfilippo syndrome patients (including those with Sanfilippo B) indicate that they experience a substantial loss of health-related quality of life (QoL) and a high level of anxiety and depression $[16,17]$.

Because of the progressive nature of Sanfilippo B, caregiver burden is believed to remain high throughout the patient's lifetime. Shapiro et al. (2015) have shown that the trajectory of Sanfilippo B is associated with increased problems in areas concerning lack of fear, lack of impulse control, and lack of social reciprocity as the patient ages [18]. As the patient ages and the disease advances, the provision and requirements of care change and impact all aspects of family life [4].

Given the challenges and high caregiver burden associated with Sanfilippo B, a meeting of clinical advisors was convened to better understand the family experience of caring for patients with Sanfilippo B and how their experiences have changed and evolved as patients age. The outcomes from this consensus panel discussion are reported here.

\section{Methods}

An international panel of clinical advisors with expertise in the care of pediatric patients with Sanfilippo B and lysosomal storage disorders was convened for a 1-day face-to-face meeting in London, UK. The panel included a pediatric physician, neuropsychologist, endocrinologist, metabolic specialists, and neurogeneticist; one of the participants was also a parent caregiver. The meeting was organized and facilitated by ICON plc (North Wales, PA, USA) and supported by BioMarin Pharmaceuticals Inc. (Novato, CA, USA).

During the meeting, 3 phases of secondary research provided necessary background information for the discussions of the clinical advisors panel to better understand and characterize caregiver burden associated with patients with Sanfilippo B. This secondary research, undertaken by BioMarin Pharmaceuticals Inc., included (1) qualitative research with parents and caregivers, (2) qualitative research with global Sanfilippo B experts, and (3) quantitative research with global clinicians (treaters)/ patient advocates for Sanfilippo B (Table 1). The objective of the qualitative research was to provide the clinical advisors with necessary information to assist with their deliberations and recommendations to better understand the family experience of caring for patients with Sanfilippo B, including how caregivers' experiences change with disease progression, identification of parent and sibling stressors, and to assess the range of experts' clinical perception of caregiver burden as well as identification of unmet needs in the treatment and care support of Sanfilippo B. A copy of the questionnaire used during the background qualitative research is provided as Additional file 1 . The objective of the quantitative research was to measure clinical perception of caregiver burden, understand clinicians' perspective on the level of caregiver stress and burden, and identify priorities for treatment and caregiver support.

\section{Results}

During the meeting, opinion from the panel was obtained in the following areas based on the data presented: source and magnitude of caregiver burden and challenges of early diagnosis, impact of caregiver burden 
Table 1 Phases of Secondary Research

\begin{tabular}{|c|c|c|c|c|}
\hline Secondary Research Phase & Research Dates & Method & Participants & Demographics \\
\hline Qualitative & March and May 2015 & $\begin{array}{l}\text { 60-min telephone } \\
\text { interview }\end{array}$ & $\begin{array}{l}26 \text { parents caring for } \\
\text { children with Sanfilippo B }\end{array}$ & $\begin{array}{l}9 \text { countries: United States }(n=6), \text { United } \\
\text { Kingdom }(n=5) \text {, Spain }(n=4), \text { Turkey }(n=4), \\
\text { Japan }(n=3) \text {, Argentina }(n=1) \text {, Brazil }(n=1), \\
\text { Canada }(n=1) \text {, and Portugal }(n=1)\end{array}$ \\
\hline Qualitative & April and June 2017 & $\begin{array}{l}\text { 45-min web-enabled } \\
\text { telephone interview }\end{array}$ & $\begin{array}{l}5 \text { global clinical experts } \\
\text { in Sanfilippo B }\end{array}$ & $\begin{array}{l}5 \text { countries: Australia, Brazil, Spain, Turkey, and } \\
\text { the United States ( } n=1 \text { for each country) }\end{array}$ \\
\hline Quantitative & July and August 2017 & Online survey & $\begin{array}{l}46 \text { Sanfilippo clinicians } \\
\text { and patient advocates }\end{array}$ & $\begin{array}{l}12 \text { countries: United States }(n=10) \text {, Brazil } \\
(n=9) \text {, Colombia }(n=7) \text {, Argentina }(n=4) \text {, } \\
\text { France }(n=3) \text {, Turkey }(n=3) \text {, Germany } \\
(n=2) \text {, Italy }(n=2) \text {, Spain }(n=2) \text {, United } \\
\text { Kingdom }(n=2) \text {, Australia }(n=1) \text {, and } \\
\text { Portugal }(n=1) \\
\text { Specialties included geneticist/neurogeneticist } \\
(n=17) \text {, metabolic specialist }(n=12) \text {, pediatric } \\
\text { neurologist }(n=6) \text {, neurologist }(n=3) \text {, } \\
\text { pediatrician }(n=3) \text {, and other }(n=5)\end{array}$ \\
\hline
\end{tabular}

on the QoL of Sanfilippo B families, and mitigating disease burden. Relevant findings provided to the panel from the background qualitative and quantitative research are presented below first, followed by the opinion of the panel. The panel then provided several recommendations based on their discussion.

Among the sample of 26 caregivers, the children with Sanfilippo B had an average age of 9 years (range, 4-50 years), with 9 patients $\leq 6$ years and 21 patients $>6$ years; 4 patients had the attenuated phenotype ( $\geq 25$ years; range, $25-50$ years).

\section{The source and magnitude of caregiver burden and the challenges of early diagnosis Background research findings}

Caregiver burden remains high throughout the life of the affected child but changes as symptoms progress (Fig. 1a). The average time from the appearance of initial symptoms to a confirmed diagnosis was 3 years (range, 1-9 years), with an average age at diagnosis of 4.8 years (range, 1.5-12 years). The major sources of impact on caregiver burden were the emotional impact of coping with the disease on a daily basis, associated behavioral factors (especially 'aggressiveness', hyperactivity, impulsiveness, and sleep disturbances), and communication difficulties with the child. Clinicians recognized physical symptoms such as loss of mobility and sleep disturbances in patients about 7 and 2 years earlier, respectively, than parents. Behavioral symptoms such as 'aggressiveness', hyperactivity, and lack of fear were recognized by clinicians about 1 to 2 years earlier than parents. In contrast, parents recognized the onset of speech deficits in their child before clinicians (Fig. 1b). Other important sources of caregiver burden were impact on the ability to work and financial stability, physical demands of providing care, QoL of caregivers, and impact on the family.
The psychological stress and physical exhaustion experienced by parents due to the continual caregiver burden leads to feelings of isolation and depression that are reinforced by the child's progressive loss of acquired skills as the disease progresses.

\section{Panel findings}

The disease progression and burden timelines identified during the secondary research were more protracted compared with the panel's experience. In the panel's experience, diagnosis of Sanfilippo B is rarely made at infancy rather characteristic clinical features are generally recognized between age 1 and 8 years, hyperactivity peaks at 3.5 to 4 years, and key skills tend to stop developing at an earlier age (ie, from 3 years onward).

An early diagnosis can help reduce the initial caregiver burden; however, the rarity of the disease and associated subtle phenotypes mean that patients often encounter multiple physicians before being diagnosed. Overlooked screening triggers identified by the panel that should be recognized in correctly diagnosing Sanfilippo B include a slowing in and halting of development; the loss of acquired skills; and physical symptoms including subtle features of dysmorphia (including macrocephaly), joint stiffness, and hirsutism (especially in eyebrows). In addition, tests such as enzymatic testing, urine tests for glycosaminoglycans, and genetic testing are also important in enabling a correct diagnosis.

A broader awareness of Sanfilippo B within the global medical community is needed to lessen the major sources of caregiver burden, particularly with regard to the behavioral and functional symptoms of Sanfilippo B. Age and disease stage of the patient, in particular, determine the severity and impact on QoL of caregivers and the family. The panel agreed that the perceived aggressive behavior of the child may be better described as 
a

\begin{tabular}{|c|c|c|c|}
\hline $\begin{array}{c}\text { Infancy } \\
(0-2 \text { years })\end{array}$ & $\begin{array}{c}\text { Childhood } \\
(3-9 \text { years })\end{array}$ & $\begin{array}{c}\text { Adolescence } \\
(10-17 \text { years })\end{array}$ & $\begin{array}{c}\text { Adulthood } \\
(18+)\end{array}$ \\
\hline
\end{tabular}
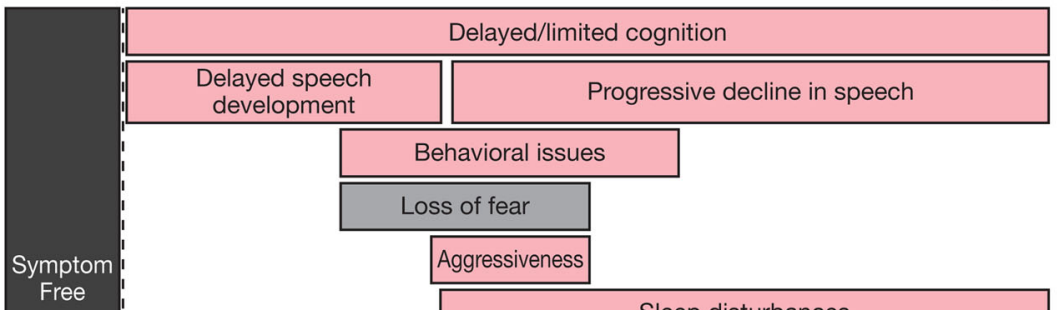

Sleep disturbances

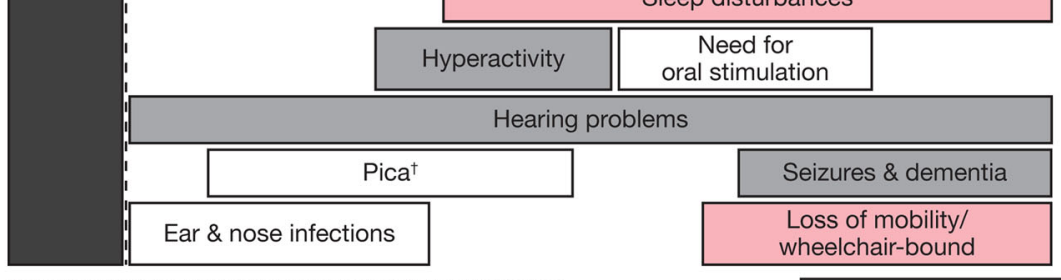

*Note: Symptoms were mentioned by respondents unprompted †Note: Pica is characterized by an appetite for substances that are largely non-nutritive; for instance, families mentioned their children eating books and paper

b

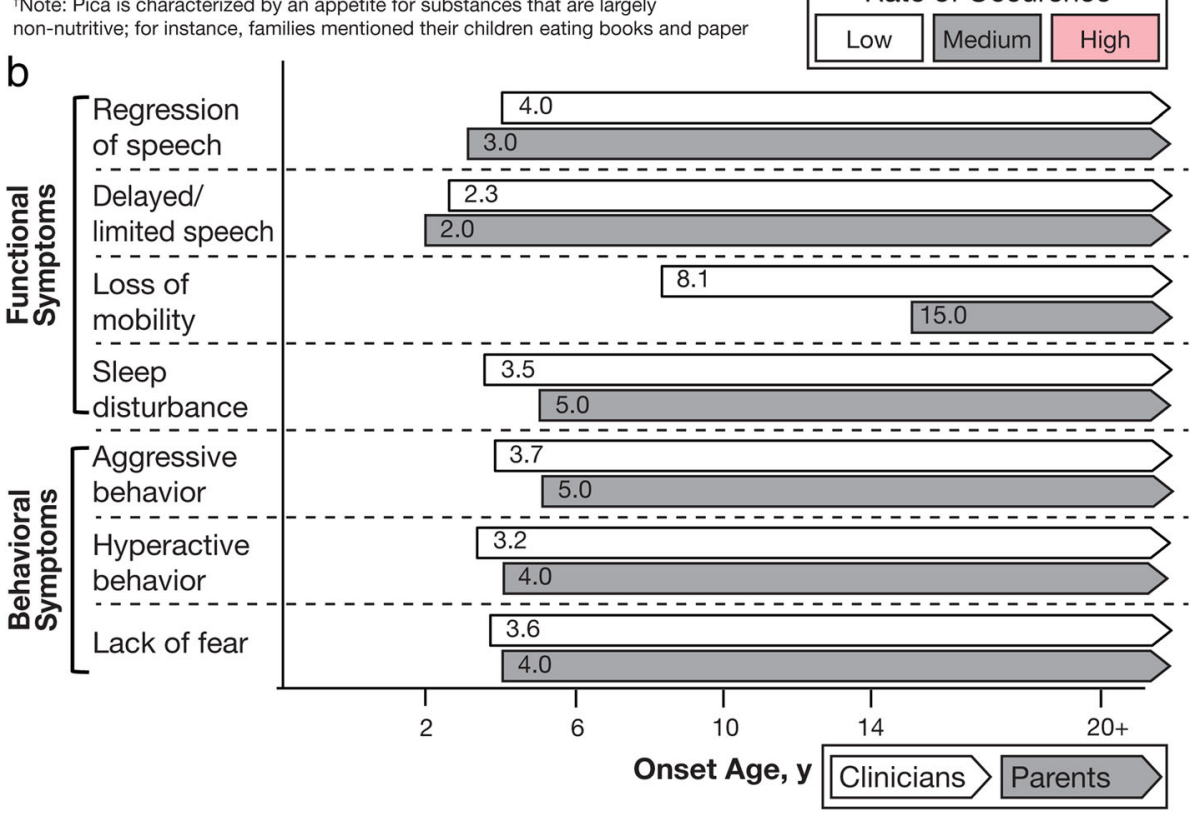

Fig. 1 a Timing of Symptoms* and $\mathbf{b}$ Recognition of Physical and Behavioral Symptoms by Parents and Clinicians

"physical impulsiveness" and is often misunderstood by the general public. Importantly, the lack of intentionality of the child's behavior is recognized and shared by parents and panel members. Parents may seek to protect their child from public scrutiny and avoid situations that many engender criticism of their parenting skills.

Overall, the panel agreed that the following are important in lessening the burden of behavioral and functional symptoms on caregivers: ability of the child to communicate broadly and functionally with parents, clearly defined criteria for measuring treatment effects, and availability of treatment.
The impact of caregiver burden on the QoL of Sanfilippo B families

\section{Background research findings}

The daily responsibilities of the caregiver leave little time to focus on anything else (Table 2). The impact of Sanfilippo $\mathrm{B}$ on the overall QoL of caregivers is influenced by emotional, social, and professional elements. The emotional impact on caregivers is driven by psychological stressors (eg, anxiety, depression) and cumulative physical exhaustion associated with caring for the patient. Families are often restricted in doing normal activities, which leads to feelings of social isolation. Career development 
Table 2 Responsibilities of the Caregiver

\begin{tabular}{|c|c|}
\hline \multicolumn{2}{|l|}{ Dealing With Behavioral Issues } \\
\hline Aggressiveness $^{\mathrm{a}}$ & $\begin{array}{l}\text { Parents need to be on constant watch } \\
\text { for potential people (eg, other children } \\
\text { or elderly) that their child may harm }\end{array}$ \\
\hline Loss of fear & $\begin{array}{l}\text { Because children with Sanfilippo B } \\
\text { are delayed cognitively, they do not } \\
\text { recognize the inherent dangers of } \\
\text { - Crossing the street without an adult } \\
\text { - Walking into the deep end of a pool } \\
\text { (and not being able to swim) } \\
\text { - Putting their hands into very hot water } \\
\text { - Eating anything that they can reach }\end{array}$ \\
\hline Hyperactivity & $\begin{array}{l}\text { Hyperactive children physically exhaust } \\
\text { parents, who may need to chase after } \\
\text { them going from room to room or } \\
\text { keep them out of harm's way }\end{array}$ \\
\hline \multicolumn{2}{|l|}{ Day-to-Day Functioning } \\
\hline Sleep issues & $\begin{array}{l}\text { Waking up in the middle of the night } \\
\text { several times to check on the child } \\
\text { and/or having the affected child wake } \\
\text { up the parents due to child's sleep } \\
\text { disturbance can have a cumulative } \\
\text { detrimental impact on the parents' } \\
\text { ability to function }\end{array}$ \\
\hline Transportation & $\begin{array}{l}\text { Getting children to and from } \\
\text { doctor's appointments and into } \\
\text { cars (staying still) }\end{array}$ \\
\hline Medication administration & $\begin{array}{l}\text { Ensuring that children receive } \\
\text { medications when needed can } \\
\text { be particularly challenging when } \\
\text { their children do not follow } \\
\text { directions }\end{array}$ \\
\hline $\begin{array}{l}\text { Bathing/grooming/ } \\
\text { toilet/dressing }\end{array}$ & $\begin{array}{l}\text { General grooming/hygiene and } \\
\text { toilet duties like bathing, brushing } \\
\text { teeth, and brushing/combing hair }\end{array}$ \\
\hline Food preparation & $\begin{array}{l}\text { Preparing the majority of meals } \\
\text { at home because going out is } \\
\text { generally considered troublesome }\end{array}$ \\
\hline $\begin{array}{l}\text { Mobility assistance } \\
\text { (wheelchair) }\end{array}$ & $\begin{array}{l}\text { Helping the child get around; climbing } \\
\text { staircases can be particularly tiring, } \\
\text { especially if wheelchair transportation } \\
\text { is involved }\end{array}$ \\
\hline
\end{tabular}

${ }^{\mathrm{a}}$ The term aggressiveness refers to perceived disruptive behavior

and professional aspirations are often halted or limited, and financial concerns may become an issue. The level of impact on the QoL of the child and family will differ depending on the age, symptoms, and behavior of the patient (Fig. 2).

\section{Panel findings}

There is a continuum of symptoms and behaviors that have a cumulative impact on caregiver burden and the QoL of families. The changing care needs of the patient lead to a "stress cycle" associated with the emergence and evolution of symptoms and associated needs of the patient as the disease progresses (Fig. 3).

Caregiver burden can fluctuate depending on day-today circumstances, such as poor sleeping patterns or stressful environments that exacerbate behaviors. For example, recognition of sleep disturbances may be due to differences in definition and may be noted by parents before clinicians. Because the child's sleeping pattern cannot be broken, parents may normalize this behavior and often sleep with their child, as this may lead to decreased stress.

Neurologic abnormalities present additional challenges such as mood problems (eg, episodes of distress triggered by specific incidents), but these are often timelimited, differ by the phase of the disease, and may be viewed as more intense at onset by siblings and other relatives. Communication between the parent and child can also be challenging. Although other forms of communication beyond speech are available, parents may not be aware of these services or be able to justify the child's need for such interventions to therapists or insurance providers.

Disease progression can be rapid, and parent expectations can change; thus, physicians must provide realistic expectations regarding the impact on the patient and family. In general, caregiver burden shifts over time from managing behavioral issues to the provision of physical and medical care as the skills acquired by the child are lost. The impact this has on families is often overlooked and may be displayed via compensatory coping mechanisms (eg, carrying the child or limiting social engagements). Siblings may receive less attention from their parents, resulting in less communication with parents and a feeling of social isolation. The long-term effects on siblings is unclear. Overall, the panel agreed that given the burden placed on caregivers and families, early counseling, mental health screening of parents and family members, and a support network are vital.

\section{Mitigating disease burden Panel findings}

A number of supportive measures could be put in place to mitigate caregiver burden (Table 3). The panel agreed that many of these supportive measures should be introduced early to set realistic expectations and minimize the emotional and physical burden associated with the disorder.

\section{Panel recommendations}

\section{Development of a Sanfilippo-specific QoL questionnaire}

Although generic caregiver and patient questionnaires have been used to assess various forms of mucopolysaccharidosis [9, 19-21], a Sanfilippo-specific QoL questionnaire is needed to help better align caregiver and clinician assessments of caregiver burden. This could be a generic Sanfilippo-specific QoL questionnaire as Sanfilippo B differs little from type A. Specific QoL questionnaires have been developed for other degenerative neurologic disorders in adults such as Alzheimer disease [22, 23] and 


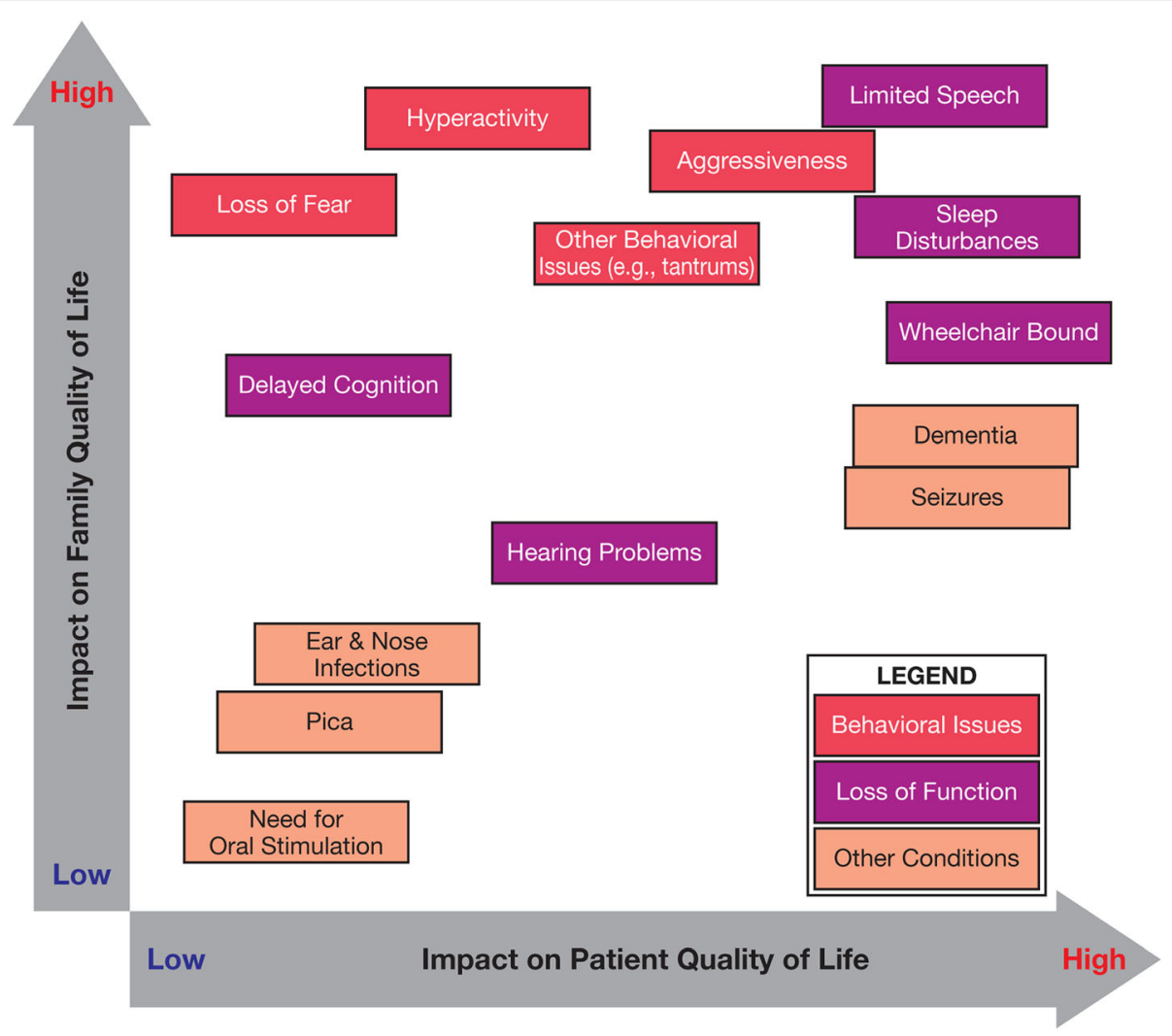

Fig. 2 Impact of Symptoms and Behaviors on Quality of Life of Child and Family

Huntington disease $[24,25]$. Additionally, the direct and indirect economic impact of conditions such as Dravet syndrome [26] or tuberous sclerosis [27] may be useful in guiding the development of a Sanfilippo-specific QoL question, given that these conditions are associated with similar issues (eg, multiple comorbidities, reduced QoL for patient and caregiver, reduced work productivity for caregiver). The questionnaire would allow clinicians to better understand the effects on caregivers in terms of their emotional, physical, mental, and social well-being and the impact that care has on the financial status of the caregiver. Development of a questionnaire presents an opportunity to properly define the aspects of the disease that most affect QoL. A phase-dependent series of questions broken down by age and phenotype is desirable. Furthermore, qualitative and quantitative measurements could be ascribed to particular symptoms or behaviors, such that patient symptoms and response to treatment can be assessed. Although capturing normative data and validation would be challenging, information obtained from such a questionnaire would help guide treatment decisions as the disease progresses.

\section{Clinical best practice}

Clinicians should develop good relationships with the families of Sanfilippo B patients through direct, regular personal contact. Such interaction should include counseling and a full explanation of the patient's journey at initial diagnosis; management of caregiver expectations regarding diagnosis, symptoms, caregiver burden, and disease progression; and early introduction of quality palliative and respite care. Although management of patients with Sanfilippo B varies by country, the development of an interdisciplinary clinical network that promotes integration of care should be the standard of care. The clinical network can assist in streamlining hospital visits and laboratory investigations, promoting early engagement with support organizations to assist families, and actively monitoring QoL of patients and caregivers, with the ability to initiate referrals for depression screenings where appropriate. Ultimately, treatment guidelines are needed.

\section{The role of treatment in alleviating caregiver burden}

Curative treatment is the preferred solution; however, this is not currently a viable option. Although there are a number of different treatments currently under development, the panel believes that treatments that slow disease progression are equally as valuable as treatments that maintain function. As with other progressive neurologic diseases for which no curative treatment is currently available, treatment goals for Sanfilippo B should be 


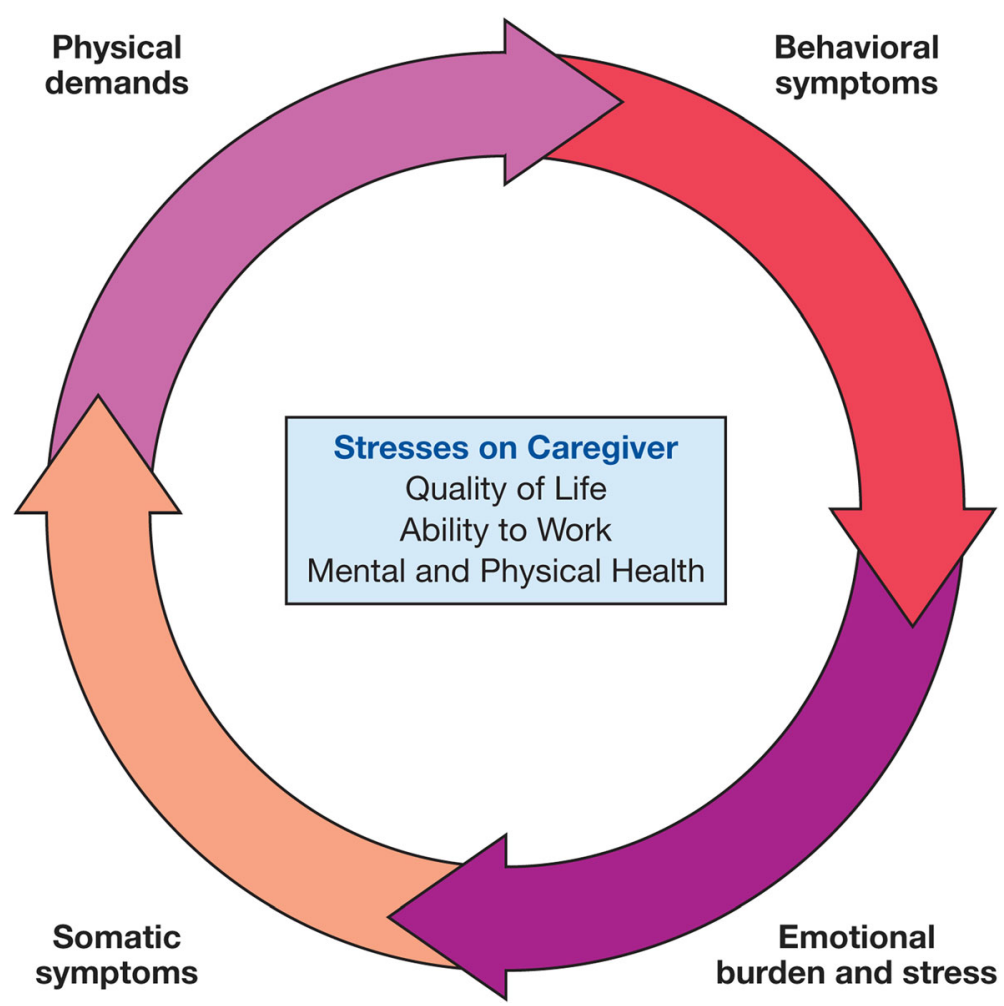

Fig. 3 Caregiver Stress Cycle. As the patient ages, the level of burden remains high, but requirements of care change as the disease progresses. Parents and caregivers experience new stresses as they encounter different symptoms and behaviors. The stress cycle of caregiver burden repeats as caregivers readjust to the changing needs of the patient, which has a detrimental effect on the quality of life of the caregiver

Table 3 Supportive Measures That Can Mitigate Caregiver Burden

\begin{tabular}{lll}
\hline Support Measure & Benefit for Patient and Caregiver & Outcome Measure \\
\hline Counseling services & $\begin{array}{l}\text { Better understand disease course } \\
\text { Manage expectations } \\
\text { Early introduction to quality palliative care }\end{array}$ & $\begin{array}{l}\text { Defined acceptable outcome for the } \\
\text { patient and their families }\end{array}$ \\
Adjunctive treatment & $\begin{array}{l}\text { Alleviate somatic symptoms, including sleep } \\
\text { disturbances and gastrointestinal symptoms }\end{array}$ & $\begin{array}{l}\text { Reduced physical burden } \\
\text { Reduced adverse events with predictable } \\
\text { management } \\
\text { Reduced nonattendance at school and work } \\
\text { Cost savings }\end{array}$ \\
Psychiatric support & Manage/support emotional stresses, anxiety, & $\begin{array}{l}\text { Less impact on social services } \\
\text { allow caregivers to effectively perform duties } \\
\text { Interdisciplinary clinical network }\end{array}$ \\
& $\begin{array}{l}\text { and depression } \\
\text { Promotes integration and coordination of care }\end{array}$ & $\begin{array}{l}\text { Reduced caregiver stress } \\
\text { Improved productivity/time management }\end{array}$
\end{tabular}

Promotes e organizations

Actively monitors QoL of patients and caregivers

Support network/parent groups and patient associations

Relief from physical tasks

Sharing of experiences

Exchange of information on support services

Financial assistance

Supports any potential loss of income

Facilitates patient travel and home modifications

Provision of respite and palliative care

Allows caregivers time to themselves Allows time for planning and assessment of the value of continual and quality care
Defined acceptable outcome for the

Reduced physical burden

Reduced adverse events with predictable

Cost savings

Less impact on social services

Reduced caregiver stress

mproved productivity/time management

Reduced emotional and physical burden

Reduced emotional, social, and professional burden

Reduced emotional and physical burden 
focused on the following 3 areas: (1) slowing disease progression and cognitive decline, as reversal of symptoms are not expected, (2) improving the QoL for patients and caregivers, and (3) treating physical and behavioral symptoms. Palliative support is vital, regardless of whether treatment halts disease progression.

\section{Discussion}

This report identifies and describes the primary, and potentially modifiable, caregiver needs for patients with Sanfilippo B and illustrates the impact of these needs on the burden among caregivers. The research findings presented here and to the clinical advisors panel were based on a small sample of clinicians and caregivers and a recall bias may, in part, account for differences in experiences of clinicians versus the medical record.

Caregiver burden is dynamic and is impacted by the age and disease stage of the patient. As a result, caregiver burden remains high throughout the patient's life, with caregivers experiencing a disease-specific and predominantly negative impact on QoL. The research findings revealed differences between the timing of symptom recognition by parents compared with clinicians. Loss of mobility was recognized much earlier by clinicians than parents, who may take pragmatic compensatory steps to cope (eg, carrying the child) with the situation; however, there is currently no consistent definition used by clinicians or caregivers as to what constitutes loss of mobility. Clinicians also recognized disturbed sleeping patterns in patients earlier than parents, who may manage this by adapting and normalizing their sleep patterns to decrease stress. As shown in Fig. 2, the impact of seizures on patient QoL was high but affected family QoL to a lesser degree. This moderate effect of seizures on family QoL was similar to that reported in studies of epilepsy and other less prevalent long-term neurologic conditions [28]. The lesser impact that seizures has on family QoL may relate to the episodic nature of these traumatic events compared with the overall impact of the physical demands and stress of coping with the daily needs of the patient.

\section{Conclusion}

The panel findings indicate that to alleviate caregiver burden, a wide range of Sanfilippo B-specific interventions and support services should be provided that not only target the behavior and symptoms of the patient but are also sensitive to the changing needs of the caregiver's burden as the disease progresses and provides support to the caregiver's mental and physical health needs. The panel recommends development of a Sanfilippo-specific QoL questionnaire and specific guidance on best clinical practice for patients with Sanfilippo B, as well as recognition of the important role treatment has in alleviating caregiver burden.

\section{Additional file}

Additional file 1: Mucopolysaccharidosis IIIB Research Discussion Guide Complete questionnaire used for the secondary background research that the clinical advisors used to inform their discussion and recommendations. (PDF $447 \mathrm{~kb}$ )

\section{Abbreviations}

MPS III: Mucopolysaccharidosis type III; QoL: Quality of life

\section{Acknowledgments}

We thank the participants for their cooperation in this research. The research and analysis into caregiver burden was conducted by Earlene Biggs at MediMedia Managed Markets (Yardley, PA), an ICON Group company, and funded by BioMarin Pharmaceuticals Inc. Editorial support for development of this manuscript was provided by Alan Storey, PhD, and Maryann T. Travaglini, PharmD at Complete Healthcare Communications, LLC (North Wales, PA), an ICON Group company, and funded by BioMarin

Pharmaceuticals Inc.

\section{Authors' contributions}

All authors participated in the meeting of international clinical advisors, had access to the research and analysis into caregiver burden, and approved the final manuscript as submitted and agreed to be accountable for all aspects of the work.

\section{Authors' information}

Not applicable.

\section{Funding}

Support for the research into caregiver burden and convening the expert panel was provided by BioMarin Pharmaceuticals Inc. (Novato, CA, USA).

\section{Availability of data and materials}

The dataset supporting the conclusions of this article are provided in this article and no additional data are available to post to any repository.

\section{Ethics approval and consent to participate}

The secondary research is based on survey data and thus no ethics approval was required. The secondary research was based on survey data in which the participants agreed to answer. No formal consent was required.

\section{Consent for publication}

Not applicable.

\section{Competing interests}

ES reports consulting fees from Shapiro Neuropsychology Consulting, LLC. CML has received honoraria for speakers' fees from Actelion, Genzyme, and Shire HGT; all fees are donated to the CML Medical Foundation for Research and Genetic Diagnosis Support for families with unknown genetic disorders. NM is a consultant for BioMarin, Shire, Genzyme Sanofi, Lysogene, and SOBI; has received grants/research support from BioMarin, Shire, and Genzyme Sanofi; and has received honoraria and travel grants from BioMarin, Shire, Genzyme Sanofi, Actelion, and Amicus. CO'N and NOM declare they have no competing interests. SV has received research support from Alexion Pharmaceuticals; has received travel grants from Actelion, BioMarin, Genzyme, and Shire; and has served as an advisory board member for Vtesse.

\section{Author details}

'Shapiro Neuropsychology Consulting, LLC, 820 NW 12th Avenue, Portland, OR 97209, USA. '2University of Minnesota, Minneapolis, MN, USA. ${ }^{3}$ Faculdade de Medicina, Centro Universitario Estácio de Ribeirão Preto, Ribeirão Preto, SP, Brazil. ${ }^{4}$ Cukurova University, Adana, Turkey. ${ }^{5}$ University Medical Center Hamburg-Eppendorf, Hamburg, Germany. ${ }^{6}$ Cure Sanfilippo Foundation, Columbia, SC, USA. ${ }^{7}$ Birmingham Children's Hospital, Birmingham, UK. 
Received: 24 January 2019 Accepted: 26 June 2019

Published online: 08 July 2019

\section{References}

1. Andrade F, Aldamiz-Echevarria L, Llarena M, Couce ML. Sanfilippo syndrome: overall review. Pediatr Int. 2015;57:331-8.

2. Fedele AO. Sanfilippo syndrome: causes, consequences, and treatments. Appl Clin Genet. 2015;8:269-81

3. Lavery C, Hendriksz CJ, Jones SA. Mortality in patients with Sanfilippo syndrome. Orphanet J Rare Dis. 2017;12:168

4. Somanadhan S, Larkin PJ. Parents' experiences of living with, and caring for children, adolescents and young adults with mucopolysaccharidosis (MPS). Orphanet J Rare Dis. 2016:11:138.

5. Wolfenden C, Wittkowski A, Hare DJ. Symptoms of autism spectrum disorder (ASD) in individuals with mucopolysaccharide disease type III (Sanfilippo syndrome): a systematic review. J Autism Dev Disord. 2017;47: 3620-33.

6. Heron B, Mikaeloff Y, Froissart R, Caridade G, Maire I, Caillaud C, et al. Incidence and natural history of mucopolysaccharidosis type III in France and comparison with United Kingdom and Greece. Am J Med Genet A. 2011, 155A:58-68.

7. Valstar MJ, Ruijter GJ, van Diggelen OP, Poorthuis BJ, Wijburg FA. Sanfilippo syndrome: a mini-review. J Inherit Metab Dis. 2008:31:240-52.

8. Wijburg FA, Wegrzyn G, Burton BK, Tylki-Szymanska A. Mucopolysaccharidosis type III (Sanfilippo syndrome) and misdiagnosis of idiopathic developmental delay, attention deficit/hyperactivity disorder or autism spectrum disorder. Acta Paediatr. 2013;102:462-70.

9. Fraser J, Gason AA, Wraith JE, Delatycki MB. Sleep disturbance in Sanfilippo syndrome: a parental questionnaire study. Arch Dis Child. 2005;90:1239-42.

10. Valstar MJ, Bruggenwirth HT, Olmer R, Wevers RA, Verheijen FW, Poorthuis BJ, et al. Mucopolysaccharidosis type IIIB may predominantly present with an attenuated clinical phenotype. J Inherit Metab Dis. 2010;33:759-67.

11. Kuiper GA, Meijer OLM, Langereis EJ, Wijburg FA. Failure to shorten the diagnostic delay in two ultra-orphan diseases (mucopolysaccharidosis types I and III): potential causes and implications. Orphanet J Rare Dis. 2018;13(2).

12. Brady J, Trehan A, Landis D, Toro C. Mucopolysaccharidosis type IIIB (MPS IIIB) masquerading as a behavioural disorder. BMJ Case Rep. 2013; https:// doi.org/10.1136/bcr-2013-009592. (e-publication ahead of print)

13. Buhrman D, Thakkar K, Poe M, Escolar ML. Natural history of Sanfilippo syndrome type a. J Inherit Metab Dis. 2014;37:431-7.

14. Deshpande S, Sathe KR. A child with advanced mucopolysaccharidosis presenting with severe behavioural problems. ASEAN J Psychiatry. 2015; 16:127-30.

15. Shapiro E, King K, Ahmed A, Rudser K, Rumsey R, Yund B, et al. The neurobehavioral phenotype in Mucopolysaccharidosis type IIIB: an exploratory study. Mol Genet Metab Rep. 2016;6:41-7.

16. Pentek M, Gulacsi L, Brodszky V, Baji P, Boncz I, Pogany G, et al. Social/economic costs and health-related quality of life of mucopolysaccharidosis patients and their caregivers in Europe. Eur J Health Econ. 2016:17(suppl 1):89-98.

17. Grant S, Cross E, Wraith JE, Jones S, Mahon L, Lomax M, et al. Parental social support, coping strategies, resilience factors, stress, anxiety and depression levels in parents of children with MPS III (Sanfilippo syndrome) or children with intellectual disabilities (ID). J Inherit Metab Dis. 2013:36:281-91.

18. Shapiro EG, Nestrasil I, Ahmed A, Wey A, Rudser KR, Delaney KA, et al. Quantifying behaviors of children with Sanfilippo syndrome: the Sanfilippo behavior rating scale. Mol Genet Metab. 2015:114:594-8.

19. Hendriksz CJ, Berger Kl, Lampe C, Kircher SG, Orchard PJ, Southall R, et al. Health-related quality of life in mucopolysaccharidosis: looking beyond biomedical issues. Orphanet J Rare Dis. 2016;11:119.

20. Needham M, Packman W, Quinn N, Rappoport M, Aoki C, Bostrom A, et al. Health-related quality of life in patients with MPS II. J Genet Couns. 2015;24:635-44.

21. Wiklund I, Raluy-Callado M, Chen WH, Muenzer J, Fang J, Whiteman D. The hunter syndrome-functional outcomes for clinical understanding scale (HSFOCUS) questionnaire: item reduction and further validation. Qual Life Res. 2014:23:2457-62

22. Galen Research. Alzheimer's Carer's Quality of Life Instrument (ACQLI) [https://eprovide.mapi-trust.org/instruments/alzheimer-s-carer-s-quality-oflife-instrument]. Accessed 28 June 2019.
23. Vickrey BG, Hays RD, Maines ML, Vassar SD, Fitten J, Strickland T. Development and preliminary evaluation of a quality of life measure targeted at dementia caregivers. Health Qual Life Outcomes. 2009;7:56.

24. Aubeeluck A, Buchanan $\mathrm{H}$. The Huntington's disease quality of life battery for carers: reliability and validity. Clin Genet. 2007;71:434-45.

25. Aubeeluck A, Dorey J, Squitieri F, Clay E, Stupple EJ, De Nicola A, et al. Further evidence of reliability and validity of the Huntington's disease quality of life battery for carers: Italian and French translations. Qual Life Res. 2013:22:1093-8.

26. Strzelczyk A, Kalski M, Bast T, Wiemer-Kruel A, Bettendorf U, Kay L, et al. Burden-of-illness and cost-driving factors in Dravet syndrome patients and carers: a prospective, multicenter study from Germany. Eur J Paediatr Neurol. 2019;23:392-403.

27. Skalicky AM, Rentz AM, Liu Z, Said Q, Nakagawa JA, Frost MD, et al. Economic burden, work, and school productivity in individuals with tuberous sclerosis and their families. J Med Econ. 2018;21:953-9.

28. Karakis I, Cole AJ, Montouris GD, San Luciano M, Meador KJ, Piperidou C. Caregiver burden in epilepsy: determinants and impact. Epilepsy Res Treat. 2014;2014:808421.

\section{Publisher's Note}

Springer Nature remains neutral with regard to jurisdictional claims in published maps and institutional affiliations.

Ready to submit your research? Choose BMC and benefit from:

- fast, convenient online submission

- thorough peer review by experienced researchers in your field

- rapid publication on acceptance

- support for research data, including large and complex data types

- gold Open Access which fosters wider collaboration and increased citations

- maximum visibility for your research: over $100 \mathrm{M}$ website views per year

At $\mathrm{BMC}$, research is always in progress.

Learn more biomedcentral.com/submissions 